\title{
The formation of the enterprises human capital in the context of digitalization
}

\author{
Oksana Pirogova ${ }^{1,{ }^{*}}$, and Marina Makarevich ${ }^{1}$ \\ ${ }^{1}$ Peter the Great St. Petersburg Polytechnic University, 195251, 29 Polytechnicheskaya str., \\ St.Petersburg, Russia
}

\begin{abstract}
The use of human resources, both in the development of an individual enterprise, and in the development of the whole country, plays an important role, therefore, issues related to the formation of "human capital" and methods for assessing it are relevant today. Today, digital technologies penetrate into all spheres of the economic activity of society and contribute to the formation of a new information environment for economic entities. Digitalization as an objective process has an impact on the development of individual sectors of the national economy, including enterprises in the service sector. The article discusses the positive and negative aspects of the impact of digitalization on the activities of service enterprises. The analysis performed in the study allowed us to identify the main problems of the use of human capital in digitalization and to identify its key features. The features of the formation of human capital of enterprises in the service sector at the stages of the life cycle are considered. A technique is proposed for evaluating the effectiveness of investments in the human capital of service enterprises, which is based on a combined assessment of the elements of human capital using the CIV and MVAIC methods, as well as taking into account the life cycle stage.
\end{abstract}

\section{Introduction}

In the context of globalization and economic integration, the service sector is one of the most important components of the development of different countries, including Russia. Currently, the service sector accounts for about $60 \%$ of GDP. Recent decades have been characterized by an increasing role of the service sector in the global economy, the range of services offered is increasing, and the number of people employed in this field is growing. The service sector employs more than half of the world's working population, which is why it acts as the predominant way of satisfying human needs. Production needs to improve the quality of service and introduce mechanisms to create demand for services, which, in turn, increase the demand for industrial goods.

Thus, the above facts confirm the inevitable processes of mutual influence, integration and globalization of different spheres that affect the full development of the state and society, therefore, at present, the study of service industry enterprises is becoming

\footnotetext{
* Corresponding author: kafedra17@rambler.ru
} 
especially important, as this corresponds to modern trends in the development of market relations. Factors affecting the development of service enterprises are presented in Fig. 1.

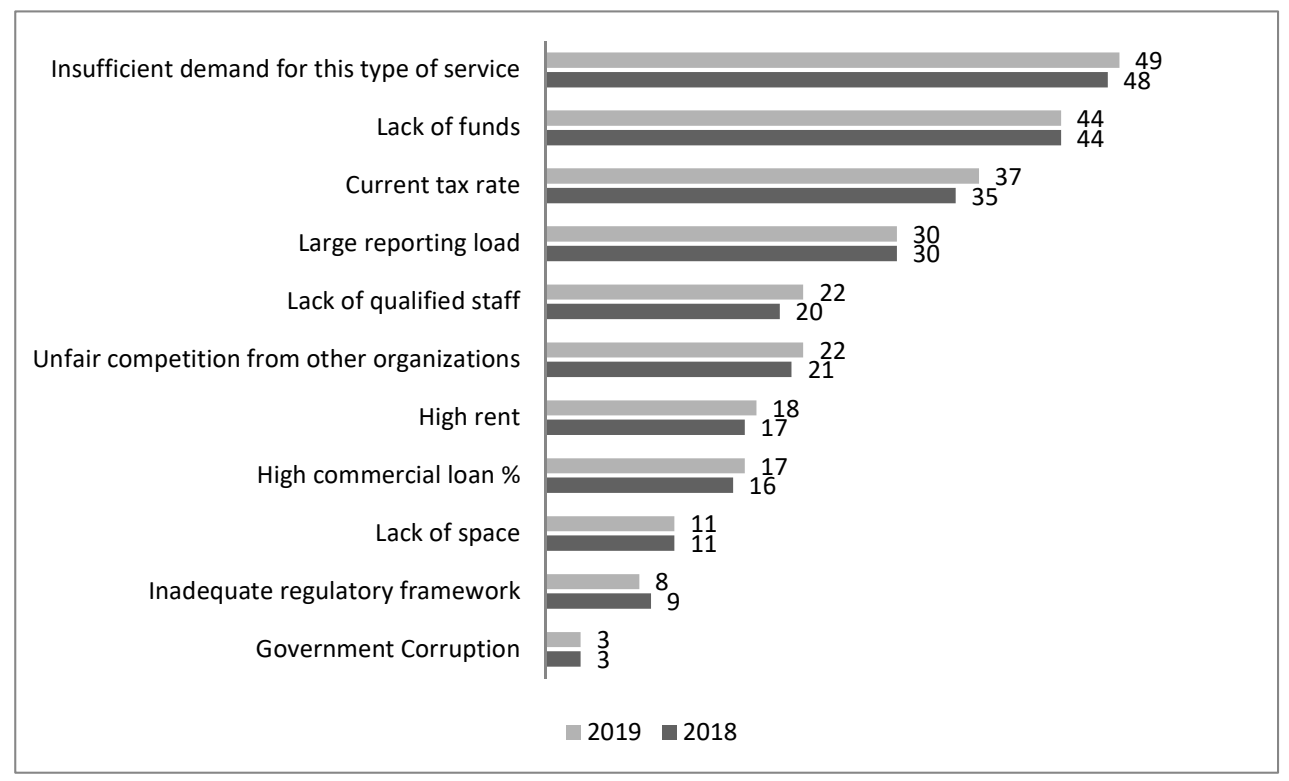

Fig. 1. Assessment of factors adversely affecting the activity of enterprises in the service sector (share of enterprises of their total number, \%) in 2018 and in 2019

In the development of an individual enterprise, and in the development of the whole country, human resources play an important role, since the more efficiently an enterprise operates, the more it makes a profit, which entails an increase in the country's GDP.

One of the promising areas in the development of modern management is the area related to human capital management.

\section{The problem of the spread of digitalization in the activities of service enterprises}

Currently, the development of the economy is characterized by the penetration of new digital technologies into all spheres of economic activity of society. This contributes to the formation of a new information environment for the interaction of economic entities, which is based on the use of information and communication technologies, digital technologies, and big data technologies. This process deeply penetrated not only economic, but also social processes and was called the process of "digitalization". Our country belongs to the group of countries in which digitalization is developing at a fairly high pace [1]. Digitalization as an objective process has a significant impact on the development of individual sectors of the economy, often leading to dramatic changes in the industry, the emergence of new types of activities of economic entities. For example, the use of digital technologies in service enterprises has led to the emergence of software services, ecommerce, digital manufacturing, data centers, which occupy a fairly large segment of the market. The impact of digitalization on the activities of service enterprises is presented in table 1 .

Using digitalization tools, service enterprises are changing their behavior model, i.e. their organizational structure, mission and goals are changing, and the speed of these 
changes is so great that the current level of development of the digitalization infrastructure does not keep pace with the changing economy [2]. In these conditions, the role of human capital in service enterprises is changing.

Table 1. The positive and negative aspects of the impact of digitalization on the activities of enterprises in the service sector

\begin{tabular}{|l|l|}
\hline $\begin{array}{l}\text { The positive impact of digitalization on the } \\
\text { activities of service enterprises }\end{array}$ & $\begin{array}{l}\text { The negative impact of digitalization on the } \\
\text { activities of service enterprises }\end{array}$ \\
\hline $\begin{array}{l}\text { decrease in the role of intermediaries, since } \\
\text { digitalization enables enterprises in the service } \\
\text { sector to independently promote and advertise } \\
\text { their services. }\end{array}$ & $\begin{array}{l}\text { exclusion of government participation in the } \\
\text { development of the digital economy }\end{array}$ \\
\hline $\begin{array}{l}\text { reduction of costs for searching and processing } \\
\text { information, reduction of transaction costs, } \\
\text { promotion costs, etc. }\end{array}$ & $\begin{array}{l}\text { reduction in the share of investments, both in } \\
\text { fixed assets and in the development of the } \\
\text { hardware base of digitalization in enterprises in } \\
\text { the service sector }\end{array}$ \\
\hline $\begin{array}{l}\text { optimization and acceleration of business } \\
\text { processes of service enterprises }\end{array}$ & $\begin{array}{l}\text { increased costs due to low investment } \\
\text { attractiveness and the introduction of } \\
\text { digitalization tools in enterprises }\end{array}$ \\
\hline $\begin{array}{l}\text { reduction of time for promotion and } \\
\text { implementation of new products and services, } \\
\text { market adaptation }\end{array}$ & $\begin{array}{l}\text { low qualifications of personnel capable of } \\
\text { effectively implementing and using digitalization } \\
\text { tools }\end{array}$ \\
\hline $\begin{array}{l}\text { increasing the flexibility and efficiency of } \\
\text { marketing strategies for service enterprises }\end{array}$ & inadequate security and the risk of digital fraud \\
\hline
\end{tabular}

Human capital is the capitalized (converted into value) current and future value of the abilities of the enterprise personnel useful for a given enterprise and its technological and economic process, embodied in the skill and qualifications of employees, and expressed in the value of the current and future incomes of the enterprise, or their excess over average market level [3].

Table 2. - Advantages and disadvantages of the impact of digitalization on the human capital of service enterprises

\begin{tabular}{|l|l|}
\hline $\begin{array}{l}\text { The positive impact of digitalization on the } \\
\text { formation of human capital }\end{array}$ & $\begin{array}{l}\text { The negative impact of digitalization on the } \\
\text { formation of human capital }\end{array}$ \\
\hline $\begin{array}{l}\text { the buyer (employee), thanks to the development } \\
\text { of digital technologies, is able to more quickly } \\
\text { receive the services that he needs }\end{array}$ & $\begin{array}{l}\text { the disappearance of certain professions due to } \\
\text { the introduction, for example, of electronic cash } \\
\text { registers or bots }\end{array}$ \\
\hline $\begin{array}{l}\text { the opportunity to save your budget, as } \\
\text { consumers can buy any things or goods on } \\
\text { online stores at lower prices }\end{array}$ & $\begin{array}{l}\text { possible increase in unemployment due to the use } \\
\text { of digitalization tools }\end{array}$ \\
\hline simplified payments in settlements & threat to the protection of personal data \\
\hline creation of additional jobs & low digital literacy \\
\hline labor productivity growth & insufficient training in education \\
\hline
\end{tabular}

\section{The impact of digitalization on the formation of human capital of service enterprises}

Currently, in the context of digitalization, service enterprises are achieving success if they develop their commercial activities using human capital.

The main problems associated with its use include the following [4]:

- insufficiently high level of development of the human capital assessment system,

- low degree of use of human capital of the enterprise 
- insufficiently thought out policies for the use of labor resources and human capital in general.

The features of human capital at the enterprise level of the service sector in the context of digitalization include:

- formed in the form of knowledge, skills, digital literacy skills of personnel in the enterprise;

- manifested in the form of abilities of labor personnel and managerial decisions they make;

- accumulates continuously in the process of involving personnel in the commercial and production process;

- investments in human capital are associated with specific workers and are expressed in increasing motivation, educational level, creative and professional abilities, etc.;

- enterprise productivity increases due to the development of digital technologies and personnel;

- a competitive advantage is formed at the enterprise, so in the process of using human capital added value is created.

Another important feature of human capital as an economic category is that it is an integral part of the intellectual capital of the enterprise, which, according to many researchers, allows the company to receive additional added value.

The concept of intellectual capital is to transform the basic financial model of an enterprise. In addition to tangible assets - fixed and working capital, another asset is added an intangible asset called intellectual capital [11]. It is the management of this asset that allows the company to form key hard copy competencies and maintain a high level of competitiveness.

The intellectual capital of the enterprise includes the human resources of the enterprise, experience and reputation, the system of working with customers and suppliers, established relationships with other stakeholders of the enterprise, the efficient use of material and digital infrastructure in which the enterprise is located [12].

The introduction of intellectual capital as a separate type of asset leads to a change in the entire financial mechanism of the enterprise. So investments in the elements of intellectual capital are considered not as costs, but as investments that are capable of making a significant contribution to the growth of the value of the enterprise in the future. At the same time, this approach also raises multiple problems associated with the lack of generally accepted mechanisms and models for assessing intellectual capital.

Intellectual capital is currently considered by many researchers as an element of capital, which forms a growth in value due to the management of factors that cannot be attributed to operational or financial. Investments in intellectual capital are considered from the perspective of investments, i.e. investments with a certain level of return, but the return is not direct, but indirect [8].

An analysis of the intellectual capital of a trading company from the point of view of the value chain concept shows that the quality of intellectual capital has a significant impact on the main goal - customer satisfaction, as well as the secondary goal - satisfying the interests of stakeholders in combination with solving the main economic task of the enterprise growth its value [13]. A higher level of intellectual capital, on the one hand, expands the number of counterparties and reduces costs when interacting with them, and on the other hand, it gives powerful positive information signals to the external environment, thereby affecting the quality of enterprise valuation from external markets.

Currently, the most common is the model of intellectual capital, which consists of three components: human capital, structural capital, consumer capital.

One of the directions of development in understanding the role of intellectual capital is an approach based on theories of the life cycle of an enterprise. In accordance with this approach, the enterprise goes through several stages in its development. 
These stages can be represented in the form of certain stages [4]. From the point of view of the enlarged analysis, one can distinguish the stages of emergence, rapid growth, maturity and the stage of bifurcation, when the development of the enterprise can go either in the direction of its further growth in value in the case of creating new values for customers and stakeholders, or embark on the path of decay when the quality of meeting needs customers will decline [5].

At the stage of origin (birth), the materialization and institutionalization of a business idea takes place and its design in the form of a working mechanism. The most important component at this stage is human capital, which includes the totality of the entrepreneurial abilities of the organizer, as well as his associates. At the same time, other types of capital structural and consumer at this stage are not yet available. Thus, thanks to human capital, the volume of knowledge and experience of individuals who united when creating the enterprise into a team is processed into a certain structure, thanks to which real investments get the opportunity to pay off in the future. If at this stage it is not possible to form human capital, then the enterprise will fail.

At the stage of rapid growth, collegiality is manifested to a large extent, the company develops its mission, strategy and goals. This stage is characterized by formalization of the rules of interaction between various members of the labor collective, i.e. elements of the cultural environment of the enterprise are being developed. At this stage, organizational capital is also formed and consumer capital is emerging, but to a lesser extent than organizational capital. Human capital continues its development in terms of clarifying the qualifications of various employees of the enterprise.

At the maturity stage, consumer capital is formed. At this stage, the existing organizational structure and competencies of employees and managers of the enterprise allow the most efficient use of mechanisms for interacting with consumers in order to increase loyalty and, as a result, increase revenue. Human capital at this stage practically does not change, however, by the end of the maturity period, it may begin to collapse, despite the fact that the business mechanisms of the enterprise are still profitable.

Stage of aging or stage of decline - is characterized by a dual possibility. This is due to the fact that the prevailing human and organizational capital cease to provide the previous efficiency of activity, i.e. the degradation of the elements of intellectual capital begins, which in turn can lead to the destruction of consumer capital. If the management of the enterprise manages to find new niches, re-engineer business processes, then the enterprise can get a second wind and the stage of development of elements of intellectual capital will be repeated again [6]. The most important role at this stage is again beginning to be played by human capital, since it is precisely the competencies of employees as well as their flexibility and ability to reorganize that can ensure the enterprise reaches a new level of development

\section{Methodology for assessing the level and effectiveness of investment in human capital of a service enterprise}

An important distinguishing feature of the approach exploring intellectual as well as human capital is the use of estimates, including cost indicators. In particular, the theory of human capital explores the dependence of the income of an employee, enterprise, society on the knowledge, skills and natural abilities of people [3]. This theory has become another step forward in economic, political, social and pedagogical views on a person, however, it has a certain specificity: people are considered not as the main value of society, but as one of the priority factors of production and economic development of the country, therefore, it is necessary to study the problems of human capital from different levels of government. 
In our opinion, the most important distinguishing features of the concept of "human capital" from the point of view of managing the economic efficiency of the activity of an enterprise in the service sector can be considered the following features:

- the carrier of human capital is a person, employee or citizen of the country, i.e. it cannot be separated from it, and without man it does not exist;

- the ability to generate additional income - i.e. ability to capitalize, i.e. on the one hand, the possibility and necessity of valuation of human capital, and on the other hand, the presence of conditions under which the knowledge and skills belonging to a person can be realized.

On the one hand, such an approach allows developing methods for assessing human capital in the future, and on the other hand developing methods for its effective management, including attraction and development (investment). At the same time, on the way to the widespread introduction of human capital in the activities of modern enterprises, there are a number of problems that have not yet been completely resolved [10].

In our opinion, the approach related to the assessment of human capital through knowledge, skills, abilities and other socially and economically important qualities of an employee is not sufficiently correct. These categories relate primarily to the term potential. But the availability of the possibility of using them in order to create a certain level of income or increase the value of the enterprise translates it already into the concept of capital. Consequently, human capital is not just knowledge, abilities and skills (competencies), but the knowledge, abilities and skills that are used or will be used in the future to generate income for the enterprise. At the same time, it is important to note that there is no direct relationship between investments in education and the return on these investments, since the general cultural features, the economic and organizational culture of the enterprise, as well as the characteristics of the employee or individual in their ability to effectively use the acquired knowledge in the process of the enterprise [11] will play a significant role.

The investment approach to the elements of intellectual capital requires an assessment of the effectiveness of investments in the development of these types of capital, which is based on a comparison of the value of investments and the return on them. Accordingly, if the amount of investments in a particular type of capital at an enterprise can be calculated quite easily, then problems arise in determining the contribution of each of the elements of intellectual capital to the growth of the value of the enterprise.

The way out of this situation can be a modified methodology for assessing the effectiveness of investments in human capital, which is based on a combination of CIV and VAIC (MVAIC) methods [14].

In accordance with the MVAIC methodology, a generalized intellectual value added coefficient is calculated:

$$
M V A I C=H C E+S C E+R C E+C E E,
$$

where: $H C E$ - shows how efficiently human capital is used (equal to the ratio of value added to labor costs);

$S C E$ - shows how efficiently organizational capital is used (equal to the ratio of value added minus human capital and value added);

$R C E$ - shows how effective is the use of relational or consumer capital (equal to the ratio of the sum of the costs of selling, advertising, marketing to value added);

$C E E$ - shows how well used capital is used.

The individual components of VAIC were calculated as follows:

$$
H C E=V A / H C,
$$


where: $\quad V A-$ value added;

$H C$ - human capital.

$$
S C E=S C / V A,
$$

where: $\quad S C-$ structure capital;

$$
C E E=V A / C E,
$$

where: $\quad C E-$ book value of net tangible assets of a company;

$$
R C E=R E / V A,
$$

where: $\quad R E-$ the amount of the costs of sales, advertising, marketing/

Thus, the three components of the MVAIC coefficient show the contribution of the elements of intellectual capital to the creation of value added. Moreover, the value added here is considered as the difference between revenues and costs.

Considering that it is intellectual capital that allows the company to earn additional profit, the value of which is higher than the industry average, it can be considered that the components of intellectual capital participate in the creation of the so-called CIV estimated intangible (intellectual) value, as a discounted flow of excess profits of the enterprise. The calculation of CIV is described in sufficient detail, for example, in [14]; therefore, we will not dwell on its calculation. Note that this indicator in itself is a monetary assessment of intellectual capital.

To assess the value of human capital, it is proposed to use the following expression as a share of intellectual capital:

$$
H C=C I V \frac{H C E}{H C E+S C E+R C E} .
$$

The resulting estimate represents the capitalized part of the company's excess profit, due to human capital.

This assessment can be compared with the amount of investment in human capital IHC, which the company carries out in the course of its activities. Here, investments in human capital are understood as additional expenses of the enterprise for the formation of a corporate culture, various trainings, retraining and staff training, expenses for maintaining the health of staff, as well as bonuses due to obtaining high results of the enterprise's activity in the reporting period. These investments do not include the costs of salaries, the search and replenishment of personnel, as these types of expenses are due to the operating activities of the enterprise.

In order to assess the effectiveness of investments in human capital in the reporting period, inequality can be used:

$$
\Delta H C_{i}>I H C_{i} \geq 0
$$

where: $\Delta H C_{i}$ - change in the human capital of an enterprise for the i-th reporting period;

$I H C_{i}$ - investments in human capital for the i-th reporting period;

If the specified inequality is satisfied, then we can conclude about the effectiveness of investment in human capital. If this equality is not fulfilled, it is necessary to revise approaches to the management of human capital in the enterprise. 


\section{Conclusion}

The article discusses the formation of human capital of service enterprises in the context of digitalization, which are debatable and relevant today. The advantages and disadvantages of the impact of digitalization on the human capital of enterprises in the service sector are considered. Features of the formation of the human capital of enterprises in the sphere at the stages of the life cycle are presented. A technique for evaluating the effectiveness of investments in the human capital of a service industry enterprise, which is based on a combined assessment of the elements of human capital using CIV and MVAIC methods, as well as taking into account the life cycle stage of a service industry enterprise is proposed. The methodology proposes criteria for evaluating the effectiveness of investing in the elements of human capital, which are based on a comparison of the intensity of human capital elements growth rates with the amount of investment in the human capital of a service company.

\section{References}

1. Y.N. Malenkov, I.V. Kapustina, V.V. Shishkin, and V.I. Shishkin, IOP Conference Series: Materials Science and Engineering, 497, 012128 (2019).

2. O. Rostova, S. Shirokova, N. Sokolitsyna and A. Shmeleva, E3S Web of Conferences 110, 02032 (2018).

3. A.R. Bril, O.V. Kalinina and O.V. Rasskazova, IBIMA 2018, 5772-5782 (2018).

4. M. Mičiak, Transportation Research Procedia 40, 1134-1140 (2019) DOI:10.1016/j.trpro.2019.07.158

5. B.S. Klaas, M. Klimchak, M. Semadeni, J.J. Holmes, Journal of Business Venturing, 25, 349-360 (2010), DOI:10.1016/j.jbusvent.2008.12.002

6. A.E. Castillo, G.V. Pacheco, L. Hernández-Fernández, E.N. Manotas, J. Silva, Procedia Computer Science 160, 567-572 (2019), DOI:10.1016/j.procs.2019.11.046L.

7. M. Prys, J. Krysińska, P. Janaszkiewicz, P. Winiecki, P. Różewski, Procedia Computer Science 126,1197-1205 (2018), DOI:10.1016/j.procs.2018.08.060

8. P. Gomes, Z. Kuehn, Review of Economic Dynamics 26, 164-179 (2017), DOI:10.1016/j.red.2017.03.004

9. S.B. Holland, Journal of Corporate Finance 46, 374-390 (2017), DOI:10.1016/j.jcorpfin.2017.08.003

10. B. Jacobs, Labour Economics 14, 913-925 (2007), DOI:10.1016/j.labeco.2007.06.008

11. M. Sevilir, Journal of Financial Intermediation 19, 483-508 (2010), DOI:10.1016/j.jfi.2009.08.002

12. C. Christiansen, J. Joensen, H. Nielsen, Labour Economics 14, 971-986 (2007), DOI:10.1016/j.labeco.2007.06.001

13. R. Almeida, P. Carneiro, Labour Economics 16, 97-106 (2009), DOI:10.1016/j.labeco.2008.06.002V.

14. Plotnikov, O. Pirogova, Y.Vertakova, IOP Conference Series: Earth and Environmental Science 272, 0322252019, DOI:10.1088/1755-1315/272/3/032225

15. O. Pirogova, E. Gorin, V. Plotnikov, E3S Web of Conferences 91, 08021 (2019)

16. V. Plotnikov, O. Pirogova, IBIMA 2018, 1716-1721 (2018). 